\title{
Matrix metalloproteinase functioning in case of esophagus acid burn.
}

\author{
Koval TV*, Ishchuk TV, Grebinyk DM, Raetska Ya B, Sokur OV, Savchuk OM, Ostapchenko LI \\ ESC "Institute of Biology and Medicine” of Kyiv Taras Schevchenko National Unversity, Kyiv, Ukraine
}

\begin{abstract}
Despite the important role of Metalloproteinase (MMP) in $\beta$-cellular matrix remodeling there is clearly not enough data concerning the MMP proteolytic activity during first three weeks (early scar changes) of postoperative gastric ulcers. Thus the main aim of our work was the MMP, TIMP-1 and bFGF overall activity determination as well as their role in post-burn wound healing in case of the $2^{\text {nd }}$ degree esophagus acid burn infliction. The greatest increase in the metalloproteinase activity and bFGF level was observed at $21^{\text {st }} \mathrm{d}$ of our experiment. In addition, the greatest increase in the TIMP-1 level in the esophageal mucosal was observed at $7^{\text {th }} \mathrm{d}$ after burn. These changes may be an evidence of chronic inflammatory processes and scar changes in rat esophagus after the EAB infliction.
\end{abstract}

Keywords: Esophagus acid burn, Matrix metalloproteinases.

Accepted on June 25, 2018

\section{Introduction}

According to the World Health Organization data, a stable growth of esophagus burn cases is clearly evident nowadays. This growth correlates with increasing availability of technical and household liquids [1]. The statistical data indicates that a major group of risk is children from 1 to 3 years of age. The most frequent situation is corneal stenosis in patients with esophagus burn diagnosis [2].

The burns are the most widespread traumatic wounds, which cause deep change in injured organism system. The endogenous intoxication and the decrease of nonspecific organism resistance, related to it, are the main causes of significant morphologic and functional tissue and organ changes. Wound healing in this case usually occurs with excessive granulated tissue formation, which often is accompanied with vast fibrosis, leading to scar contracture formations and subsequent organ function loss. As it is already known, during fibroblast proliferation collagen is produced. This collagen amount constantly increases during the first several weeks. This fibroplasia phase is accompanied by angiogenesis, which is very important for scar formation processes. If angiogenesis is too weak, it may hinder fibroblast migration and wound healing. The capillary endothelium in this case produces degrading agents such as the plasminogen activator and collagenase that leads to filling the wound with enzymes degrading both fibrous clots and scar tissues [3]. Among these enzymes there are metalloproteinases. Matrix Metalloproteinases (MMP) are representatives of a protease family involved in proteolytic degradation of extracellular matrix various components. They also carry out both regulatory and modulating functions in angiogenesis. The angiogenesis regulation is based on the balance of angiogenic and angiostatic factors, thus determining various paths of wound processes in general including burn wounds specifically. All in all, MMP presence and activity is very important for wound healing [4]. On the other hand, MMPs can prevent chronic wound healing. Recent studies have shown that chronic wounds contain many neutrophils secreting MMP-8 and elastase, which can contribute to excessive protein degradation and wound growth factor inactivation $[5,6]$. It appears that Tissue Inhibitors of Matrix Metalloproteinases (TIMP) play an important role in these processes. Consequently, proteinase activity can be considered as one of the wound healing process key components. However, the disruption of metalloproteinase functioning as well as the activator-inhibitor balance shift can lead to the various pathology developments during healing.

\section{Materials and Method}

We used white non-linear, sexually immature rats (1-month) weighing 90-101 g (corresponding to 3-4 years of age of children) in our experiments. All operations were in compliance with the general ethical principles of animal experiments ruled by the First National Congress of Ukraine on Bioethics (September 2001), as well as the others international agreements and national legislation matters in this area. The animals were kept on the standard vivarium diet. The experimentally induced acid esophagus burn was inflicted with a $30 \% \mathrm{CCl}_{3} \mathrm{COOH}$ solution corresponding to the $2^{\text {nd }}$ degree esophagus burn. The control group were once given the appropriate volume of orally injected water [7]. The animals were taken out the experiment at $1^{\text {st }}, 7^{\text {th }}, 15^{\text {th }}$ and $21^{\text {st }} \mathrm{d}$.

The TIMP-1, bFGF and MMP content was determined by the immunoassay analysis [8]. The solubilized homogenate protein material from rat esophagus was used as an antigen, diluted to the $10 \mu \mathrm{g} / \mathrm{ml}$ protein concentration with $50 \mathrm{~mol} / \mathrm{L}$ Tris- $\mathrm{HCl}$ 
buffer $(\mathrm{pH}$ 7.4). The test specimens were incubated in a volume of $100 \mu \mathrm{l}$ in a 96-well plate overnight at $4^{\circ} \mathrm{C}$. The primary polyclonal antibodies (Santa Cruz, USA), the secondary antibodies, conjugated with horseradish peroxidase (Bio-Rad, USA) and the hydrogen peroxide ophenylenediamine substrate (Sigma, USA) were also used during the study. The measurements were made at the $492 \mathrm{~nm}$ wavelength.

The statistical data processing was performed using OriginLab 8.0. The parameter changes were considered probable at $\mathrm{P}<0.05$.

\section{Results}

MMP functioning in processes of normal and pathological wound healing is currently under active research $[9,10]$. We determined the MMP-1, MMP-2, MMP-3, MMP-8 and MMP-9 content in the esophageal mucosal (Table 1) and serum (Table 2) of rats after the esophagus $2^{\text {nd }}$ degree acid burn simulation. The MMP-1 content maximum increase by $33 \%$ in rat blood serum was observed at 1th day after burning, if compared to the control values. During the next days of our study, the MMP-1 content gradually decreased, still remaining above the control. At the same time the content of MMP-1 in mucous membranes increased by $109 \%$ during the first day, while on the $7^{\text {th }} \mathrm{d}$ this parameter is found to be slightly decreased, and at the $15^{\text {th }}$ and $21^{\text {st }} \mathrm{d}$ the MMP- 1 content shows an increase again. The maximum value of MMP-1 content in mucous membranes was observed after $21 \mathrm{~d}$ in a form of $114 \%$ increase in comparison with the control.

The MMP-2 content was increased by $120 \%$ and $125 \%$ at $1^{\text {st }}$ and $15^{\text {th }} \mathrm{d}$ after mucous membrane burn inflicting, while in rat serum this parameter was increased by $83 \%$ and $80 \%$ respectively, in comparison with the control values. The MMP-3 content in esophagus mucous membranes constantly increased throughout all experimental period, and the maximum value was observed after 21 post-burn days, being $92 \%$ more than the control. In rat serum, the MMP-3 content showed no significant changes, while after $21 \mathrm{~d}$ the parameter increased by $8 \%$ if compared to the control values.

After the esophagus acid burn infliction the MMP-8 content in its mucous membranes was increased by $51 \%$ at $1^{\text {st }} \mathrm{d}$, while at the $7^{\text {th }}$ and $15^{\text {th }} \mathrm{d}$, this parameter was slightly decreased, remaining above the control values. The MMP- 8 maximum content was observed at $21^{\text {st }} \mathrm{d}$ and it was $77 \%$ higher than the control. In rat blood serum the MMP-8 content remained higher than the control values throughout the entire experimental period. This parameter highest value was observed at $7^{\text {th }} \mathrm{d}$, being $35 \%$ higher than control. A similar situation was uncovered studying the MMP-9 content in esophagus mucous membranes. Namely, it gradually increased by $40 \%$ at $1^{\text {st }} \mathrm{d}$ and by $60 \%$ at $7^{\text {th }} \mathrm{d}$ after the burn infliction. The MMP-9 content slightly decreased at $15^{\text {th }} \mathrm{d}$, still being above the control values. The maximum value of MMP-9 content in mucous membranes was observed at $21^{\text {st }} \mathrm{d}$ and it was $69 \%$ higher compared to the control values. The MMP-8 rat blood serum content was higher by $58 \%$ at $1^{\text {st }} \mathrm{d}$ and by $50 \%$ at $7^{\text {th }} \mathrm{d}$ in comparison with the control values. The highest value of this parameter was observed at $15^{\text {th }}$ and $21^{\text {st }} \mathrm{d}$-it appeared $70 \%$ higher than the control.

We have determined the TIMP-1 content in both esophagus mucous membranes and blood serum (Figure 1). In mucous membranes this parameter increased during the whole experiment. For $1^{\text {st }}$ and $7^{\text {th }} \mathrm{d}$ after the burn, TIMP-1 level was higher than the control values by $43 \%$ and $59 \%$ respectively. At $15^{\text {th }} \mathrm{d}$ this parameter level appeared to be lowered slightly remaining 20\% higher than the control. The parameter highest value was observed at $21^{\text {st }} \mathrm{d}$ after the esophagus burn modeling-it was $92 \%$ higher than the control values.

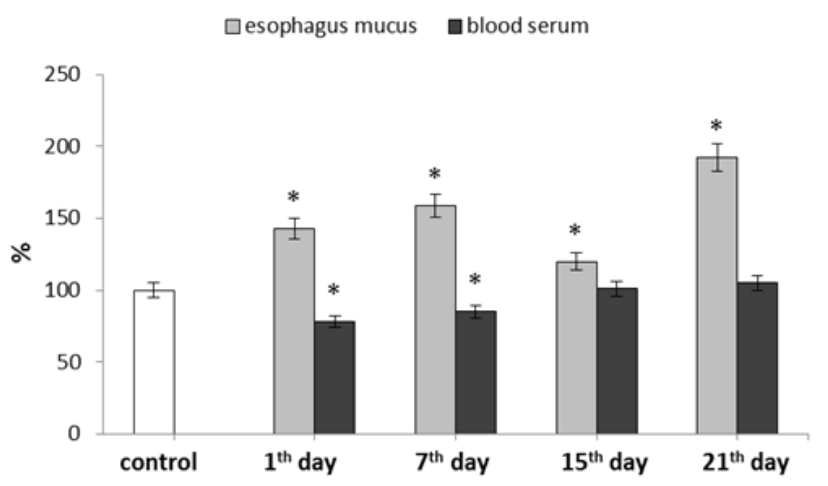

Figure 1. The TIMP content in esophagus mucous membranes and rat blood serum in case of rat esophagus acid burn infliction. ( $M \pm m$, $n=8)$.

In rat blood serum the TIMP-1 levels appeared decreased by $22 \%$ and $15 \%$ at $1^{\text {st }}$ and $7^{\text {th }} \mathrm{d}$ after the burn respectively if compared to the control. As for $15^{\text {th }}$ and $21^{\text {st }} \mathrm{d}$, the parameter was higher than the control level.

For our next step we determined the bFGF level after rat esophagus acid burn infliction (Figure 2).

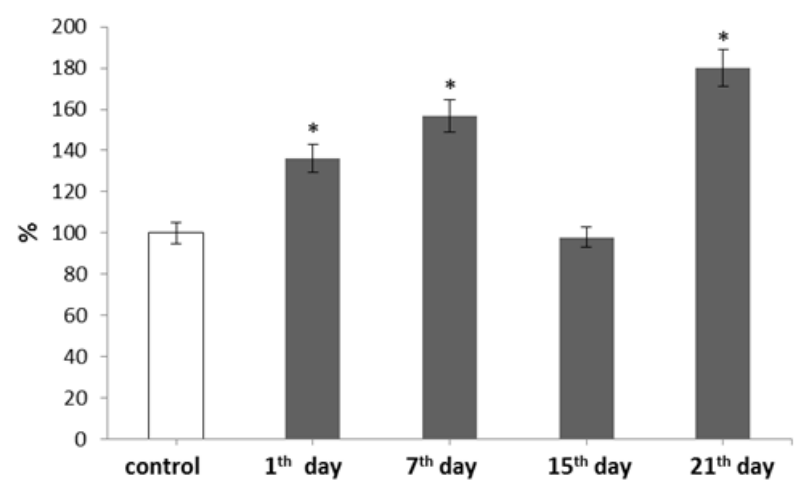

Figure 2. The bFGF level in rat esophagus mucous membranes in case of EAB development $(M \pm m, n=8) .{ }^{*} p<0.05$ relative to the control.

It was shown that the bFGF level increases during our experiment. With the development of EAB this parameter showed gradual increase reaching the maximum value at $21^{\text {st }}$ 
d-by $80 \%$ if compared to the control. The fifteenth day was an exception. During it the bFGF level decreased to the control level correlating with the MMP and TIMP levels during the given period.

Table 1. The dynamics of the matrix metalloproteinase content in esophagus mucous membranes in case of the esophagus acid burn (in $\mathrm{cu} / \mathrm{ml}) . \mathrm{M} \pm m, n=8$.

\begin{tabular}{|c|c|c|c|c|c|c|c|c|c|}
\hline & MMP-1 & & MMP-2 & & MMP-3 & & MMP-8 & & MMP-9 \\
\hline Control & $\begin{array}{l}0.145 \\
0.007\end{array}$ & \pm & $\begin{array}{l}0.128 \\
0.006\end{array}$ & \pm & $\begin{array}{l}0.113 \\
0.005\end{array}$ & \pm & $\begin{array}{l}0.085 \\
0.004\end{array}$ & \pm & $\begin{array}{l}0.110 \\
0.005\end{array}$ \\
\hline $1^{\text {st }} \mathrm{d}$ & $\begin{array}{l}0.303 \\
0.014^{*}\end{array}$ & \pm & $\begin{array}{l}0.281 \\
0.013^{*}\end{array}$ & \pm & $\begin{array}{l}0.174 \\
0.008^{*}\end{array}$ & \pm & $\begin{array}{l}0.128 \\
0.006^{*}\end{array}$ & \pm & $\begin{array}{l}0.154 \\
0.007^{*}\end{array}$ \\
\hline $7^{\text {th }} \mathrm{d}$ & $\begin{array}{l}0.214 \\
0.009^{\star}\end{array}$ & \pm & $\begin{array}{l}0.192 \\
0.009^{*}\end{array}$ & \pm & $\begin{array}{l}0.178 \\
0.008^{*}\end{array}$ & \pm & $\begin{array}{l}0.109 \\
0.005^{*}\end{array}$ & \pm & $\begin{array}{l}0.176 \\
0.008^{*}\end{array}$ \\
\hline $15^{\text {th }} d$ & $\begin{array}{l}0.251 \\
0.011^{*}\end{array}$ & \pm & $\begin{array}{l}0.288 \\
0.013^{*}\end{array}$ & \pm & $\begin{array}{l}0.183 \\
0.008^{*}\end{array}$ & \pm & $\begin{array}{l}0.111 \\
0.005^{*}\end{array}$ & \pm & $\begin{array}{l}0.134 \\
0.006^{*}\end{array}$ \\
\hline $21^{\text {st }} \mathrm{d}$ & $\begin{array}{l}0.311 \\
0.014^{*}\end{array}$ & \pm & $\begin{array}{l}0.265 \\
0.012^{*}\end{array}$ & \pm & $\begin{array}{l}0.217 \\
0.009^{*}\end{array}$ & \pm & $\begin{array}{l}0.150 \\
0.007^{*}\end{array}$ & \pm & $\begin{array}{l}0.186 \\
0.008^{*}\end{array}$ \\
\hline
\end{tabular}

* $\mathrm{p}<0.05$ relative to the control

Table 2. The dynamics of the matrix metalloproteinase content in rat blood serum in case of the esophagus acid burn (in cu/ml). $\mathrm{M} \pm m$, $n=8$.

\begin{tabular}{|c|c|c|c|c|c|c|c|c|c|}
\hline & MMP-1 & & MMP-2 & & MMP-3 & & MMP-8 & & MMP-9 \\
\hline Control & $\begin{array}{l}0.104 \\
0.005\end{array}$ & \pm & $\begin{array}{l}0.105 \\
0.005\end{array}$ & \pm & $\begin{array}{l}0.079 \\
0.004\end{array}$ & \pm & $\begin{array}{l}0.055 \\
0.002\end{array}$ & \pm & $\begin{array}{l}0.045 \\
0.002\end{array}$ \\
\hline $1^{\text {st }} d$ & $\begin{array}{l}0.138 \\
0.006^{\star}\end{array}$ & \pm & $\begin{array}{l}0.192 \\
0.009^{*}\end{array}$ & \pm & $\begin{array}{l}0.073 \\
0.003\end{array}$ & \pm & $\begin{array}{l}0.06 \\
0.003\end{array}$ & \pm & $\begin{array}{l}0.071 \\
0.003^{*}\end{array}$ \\
\hline $7^{\text {th }} d$ & $\begin{array}{l}0.13 \\
0.006^{*}\end{array}$ & \pm & $\begin{array}{l}0.148 \\
0.007^{*}\end{array}$ & \pm & $\begin{array}{l}0.077 \\
0.003\end{array}$ & \pm & $\begin{array}{l}0.074 \\
0.003^{*}\end{array}$ & \pm & $\begin{array}{l}0.067 \\
0.003^{*}\end{array}$ \\
\hline $15^{\text {th }} \mathrm{d}$ & $\begin{array}{l}0.12 \\
0.005^{*}\end{array}$ & \pm & $\begin{array}{l}0.190 \\
0.009^{*}\end{array}$ & \pm & $\begin{array}{l}0.084 \\
0.004\end{array}$ & \pm & $\begin{array}{l}0.072 \\
0.003^{*}\end{array}$ & \pm & $\begin{array}{l}0.077 \\
0.003^{*}\end{array}$ \\
\hline $21^{\text {th }} \mathrm{d}$ & $\begin{array}{l}0.11 \\
0.005\end{array}$ & \pm & $\begin{array}{l}0.141 \\
0.011^{*}\end{array}$ & \pm & $\begin{array}{l}0.085 \\
0.004\end{array}$ & \pm & $\begin{array}{l}0.069 \\
0.003^{*}\end{array}$ & \pm & $\begin{array}{l}0.075 \\
0.003^{*}\end{array}$ \\
\hline
\end{tabular}

" $p<0.05$ relative to the control

\section{Discussion}

While determining the levels of Matrix Metalloproteinase (MMP) responsible for extracellular matrix degradation, it was established that almost all MMP type content-both in esophagus mucosa and blood serum-was higher compared to the control parameters during all experiment term. The obtained results concerning the MMP content can be regarded as an evidence of scarring change development and inflammation processes, corresponding to the wound healing course.

It is known that MMP-1 is synthesized by fibroblasts, chondrocytes, macrophages, keratinocytes, endothelial cells and osteoblasts [11]. The MMP-1 significant activity is also evident in wound micro-vicinity, where it is usually produced by fibroblasts, macrophages and other granulation tissue cells [12]. The new function of MMP-1 as a vessel regression regulator in extracellular matrix components is shown. And the ability of various serine proteases to initiate MMP-1 activation leads to collagen and extracellular matrix proteolysis, as well as tissue regression [13].

Gelatinase A (MMP-2) degrades vast quantities of ECM molecules, hence inhibiting some important processes, for example-angiogenesis. High levels of MMP-2 points to the important role of this enzyme in matrix remodeling processes, and, presumably, scar resorption. As it is already known, MMP-2 is primarily expressed in mesenchymal cells (mainly in fibroblasts) during tissue development and regeneration. It is also synthesized by neutrophils, macrophages and monocytes. MMP-2 takes part in inflammation inhibition processes, influencing cytokine/chemokine processing [14].

MMP-3 catalyses degradation of connective tissue many components, including proteoglycans, collagen, laminin and fibronectin. MMP-3 is secreted as a pro-enzyme and activated by limited proteolysis performed by tissue and plasma endopeptidases in natural environment [15]. MMP-3 has the important role in natural processes of tissue remodeling and pathological processes. Low MMP-3 amount can be regarded as a treat of excessive proliferative process induction with stable fibrosis deformation development [16]. In addition, a number of authors published data confirming the MMP-2 and MMP-3 participation the processes of post-burn wound healing $[17,18]$.

The obtained results concerning the MMP- 8 content increase during initial stages of extracellular matrix degradation processes can point to this proteinase substantial role in inflammation response modulation during esophagus acid II degree burns. The MMP- 8 is a key enzyme of initial stages of extracellular matrix destruction, especially in case of pathological inflammatory processes [19]. MMP-8 can degrade such proteins as fibronectin, cartilage agrecan and serpins, as well as peptides such as angiotensin and substance $P$ [12]. MMP-8 synthesis and activity regulation by endothelial cells, smooth muscle cells and macrophages in chronic inflammation zones requires influences of pro-inflammatory cytokines [20].

MMP-9 is involved in inflammation, tissue remodeling and reparation, as well as matrix-bound growth factor mobilization and cytokine processing. This MMP favors angiogenesis through the release of angiogenic factors bound to extracellular matrix, such as VEGF. MMP-9 and MMP-2 together exert their activities in angiogenesis processes, as well as induce vessel development during vascularization initial stages. [12]. It was shown that MMP-8 and MMP-9 are able to split collagen molecules into smaller fragments [21]. Wound healing is a complex process that requires various signaling molecules and their receptors to be regulated properly. Thus, metalloproteinases are capable of transforming some of these molecules, changing their activities to achieve this goal.

Thus, during all our experiment we observed MMP amount changes in blood serum and esophagus mucosa of rats with esophagus acid II degree burns, namely we saw their content increase which allows us to propose the important role of these 
enzymes in given burn response development. MMPs take part in proteolytic degradation of extracellular matrix components, control regulating and modulating functions in angiogenesis, as well as modulate inflammation responses. MMPs are responsible for migration and extravasation of keratinocytes, fibroblasts, leucocytes, and so on, mainly through basal membrane degradation. The activity dysregulation of these proteases in wound environment can even lead to normal tissue degradation.

As it is already known, the MMP activity is regulated by specific inhibitors, one of which is the Tissue Inhibitor of Matrix Metalloproteins (TIMP). TIMP suppresses the activity of MMP in a molar ratio of $1: 1$, giving the formation of stable noncovalent complexes. Disturbance of the MMP to TIMP ratio may lead to uncontrolled proteolytic processes in majority of tissues [22]. All in all, TIMP-1 is a universal inhibitor of most MMPs [23,24]. During esophagus acid burn we observed TIMP-1 amount decrease in blood serum at the $1^{\text {st }}$ and $7^{\text {th }} d$. TIMP-1 elevated concentrations can promote tissue fibrosis, leading to pathological scar formations. Normally collagen synthesis and degradation processes in tissues are balanced due to the system of matrix metalloproteinase action with the aid of their tissue inhibitors. The post-burn wound healing process disturbance (which leads to scarring) may be due to excessive collagen synthesis caused by the ratio of MMP to TIMP imbalance [25]. In mucous membranes TIMP-1 level increased during the whole experiment. In this case there is a proteolytic activity predominance, which can lead to intercellular matrix protein degradation continuation, indicating chronic inflammation further continuation. Such unregulated proteinase activity appears to be one of the main pathological mechanisms underlying improper wound healing. Excessive proteinase activity has significant detrimental effects on collagen, thus preventing scar formation, while decay products advance inflammation. From the literature data it is known that TIMP-1 has functions which bear no relation to its inhibiting properties concerning MMPs. It has erythroid action potential, antiangiogenic and pro-fibrotic potentials, and so on. This factor can activate neutrophils and even protect them from apoptosis during sepsis [26]. Given this, we can presume that TIMP-1 can be an acute inflammation common marker. Some research data shows the level of tissue metalloproteinase inhibitors, namely TIMP-1, to appear and increase specifically in chronic wounds [12].

Fibroblasts are the main effectors of the tissue regeneration phase [27]. By the second or third day after an injury infliction many growth factors trigger fibroblast migration to the damage sites where their further proliferation continues. This process is accompanied by angiogenesis-new blood vessels growth. Thus fibroblasts appear to be the most important cells involved in extracellular matrix remodeling as well as one of the Fibroblast Growth Factor (bFGF) major target cells during healing and other processes. These fibroblast growth factors are produced by keratinocytes, fibroblasts, chondrocytes, endothelial, smooth muscle and tumor cells. According to the literature data, local bFGF applications can largely contribute to wound healing [28-30]. This bFGF increase may indicate this factor participation in both burn disease progression and post-burn wound healing processes.

\section{Conclusions}

To sum it all, during the EAB modeling we observed the significant changes in matrix metalloproteinase functioning, namely TIMP-1 and bFGF. These enzyme level changes were different in esophagus mucous membranes and in rat blood serum. In mucous membranes the maximum level of MMP-1, MMP-3, MMP-8, MMP-9 and TIMP-1 was observed at $21^{\text {st }} \mathrm{d}$ after the burn infliction, while the MMP-2 level was at its maximum at $15^{\text {th }} \mathrm{d}$ of our experiment. In rat blood serum, the level of MMP was at its maximum value at $15^{\text {th }} \mathrm{d}$, while the TIMP-1 level gained the control values within the specified time. Finally, the bFGF reached its maximum at $21^{\text {st }} \mathrm{d}$. These changes may be an evidence of chronic inflammatory processes and scar changes in rat esophagus after the EAB infliction.

\section{References}

1. DCruz R, Pang TC, Harvey JG, Holland AJ. Chemical burns in children: Aetiology and prevention. Burns 2015; 41: 764-769.

2. Dinis-Oliveira RJ, Carvalho F, Moreira R, Proenca JB, Santos A, Duarte JA, Bastos Mde L, Magalhaes T. Clinical and forensic signs related to chemical burns: a mechanistic approach. Burns 2015; 41: 658-679.

3. Abaev Yu K. Healing of acute and chronic wounds. Voennaja Meditsina 2010; 2: 106-110.

4. Petrenko OM, Tykhomyrov AO. Role of matrix metalloproteinases in wound healing processes. Med Chem 2013; 15: 100-106.

5. Amato B, Coretti G, Compagna R. Role of matrix metalloproteinases in non-healing venous ulcers. Int Wound J 2015; 12: 641-645.

6. Jeong S, Schultz GS, Gibson DJ. Testing the influence of surfactant-based wound dressings on proteinase activity. Int Wound J 2017; 14: 786-790.

7. RaetskaY, Ischuk T, Koval T, Dzhus O. Experimental modelling of an acid esophagus burn of 2 nd degree in immature rats. Bull Taras Shevchenko Nat Univ Kyiv Probl Physiol Funct Regul 2015; 2: 15-18.

8. Crowther JR. The ELISA guidebook. Humana Press Inc. 2001.

9. Bian F, Wang C, Tukler-Henriksson J. MMP-8 is critical for dexamethasone therapy in alkali-burned corneas under dry eye conditions. J Cell Physiol 2016; 231: 2506-2516.

10. Park CH, Son HU, Yoo CY, Lee SH. Low molecularweight gel fraction of Aloe vera exhibits gastroprotection by inducing matrix metalloproteinase- 9 inhibitory activity in alcohol-induced acute gastric lesion tissues. Pharm Biol 2017; 55: 2110-2115.

11. Markelova EV, Zdor VV, Romanchuk AL, Birko ON. Matrix metalloproteinases: relationship with cytokines 
system, diagnostic and prognostic potential. Immunopathol Allergol Infectol 2016; 2: 11-22.

12. Yarmolinskaya MI, Molotkov AS, Denisova VM. Matrix metalloproteinases and inhibitors: classification, mechanism of action. J Obstetr Womans Dis 2012; 61: 113-125.

13. Gioia M, Monaco S, Van Den Steen PE, Sbardella D, Grasso G, Marini S, Overall CM, Opdenakker G, Coletta $\mathrm{M}$. The collagen binding domain of gelatinase $\mathrm{A}$ modulates degradation of collagen IV by gelatinase B. J Mol Biol 2009; 386: 419-434.

14. Rodriguezac D, Morrisonac C. J, Overallabc C. M. Matrix metalloproteinases: What do they not do? New substrates and biological roles identified by murine models and proteomics. BBA Mol Cell Res 2010; 1803: 39-54.

15. Bart II, Ivanov IS, Lazarenko VA, Ivanov VP. Association of ratio of collagenes in the aponeurosis of the abdominate with a matrix metalloproteinase genes polymorphisms. Mod Probl Sci Educ 2013; 2: 28-34.

16. Visse R, Nagase H. Matrix metalloproteinases and tissue inhibitors of metalloproteinases: structure, function, and biochemistry. Circ Res 2003; 92: 827-839.

17. Caley MP, Martins VL, OToole EA. Metalloproteinases and Wound Healing. Adv Wound Care (New Rochelle) 2015; 4: 225-234.

18. Rohl J, Murray RZ. Matrix metalloproteinases during wound healing-a double edged sword. Wound Pract Res 2013; 21: 174-182.

19. TsaousiA, Witte E, Witte K. MMP8 is increased in lesions and blood of acne inversa patients: a potential link to skin destruction and metabolic alterations. Med Inflamm 2016.

20. Vanlaere I, Libert C. Matrix metalloproteinases as drug targets in infections caused by gram-negative bacteria and in septic shock. Clin Microbiol Rev 2009; 22: 224-239.

21. Hästbacka J, Freden F, Hult M, Bergquist M, Wilkman E. Matrix metalloproteinases -8 and -9 and tissue inhibitor of metalloproteinase-1 in burn patients. A prospective observational study. PLoS One 2015; 10: 0125918.

22. Peled ZM, Phelps ED, Updike DL. Matrix metalloproteinases and the ontogeny of scarless repair: the other side of the wound healing balance. Plast Reconstr Surg 2002; 110: 801-811.

23. Dietmar U, Franziska U, Frank U. Matrix metalloproteinases and tissue inhibitors of metalloproteinases in patients with different types of scars and keloids. J Plast Reconstr Aesthet Surg 2010; 63: 1015-1021.

24. Dasu MR, Spies M, Barrow RE, Herndon DN. Matrix metalloproteinases and their tissue inhibitors in severely burned children. Wound Repair Regen 2003; 11: 177-180.

25. Hutsikava LV, Paulouskaja A. The significance of matrix metalloproteinases in pathogenesis of genital endometriosis. J Grodno State Med Univ 2016; 4: 43-49.

26. Arifov SS, Magrupov AM, Urazaeva JK, Stopnickiy AA. The questions of diagnostics and treatment of chemical burns a pharynx and a gullet. Shoshilinch Tibbiyot Axborotnomasi 2009; 2: 58-60.

27. Frangogiannis NG. Fibroblast-extracellular matrix interactions in tissue fibrosis. Curr Pathobiol Rep 2016; 4: 11-18.

28. Mazer-Amirshahi M, Whitaker N, Kayewilson L. Ocular injury after button battery exposure. J Emerg Med 2013; 44: 187-189.

29. Nunes QM, Li Y, Sun C, Kinnunen TK, Fernig DG. Fibroblast growth factors as tissue repair and regeneration therapeutics. Peer J 2016; 4: 1535.

30. Hayashida K, Akita S. Quality of pediatric second-degree burn wound scars following the application of basic fibroblast growth factor: results of a randomized, controlled pilot study. Qstomy Wound Manag 2012; 58: 32-36.

\section{*Correspondence to}

Koval TV

ESC "Institute of Biology and Medicine" of Kyiv Taras Schevchenko National University

Kyiv

Ukraine 